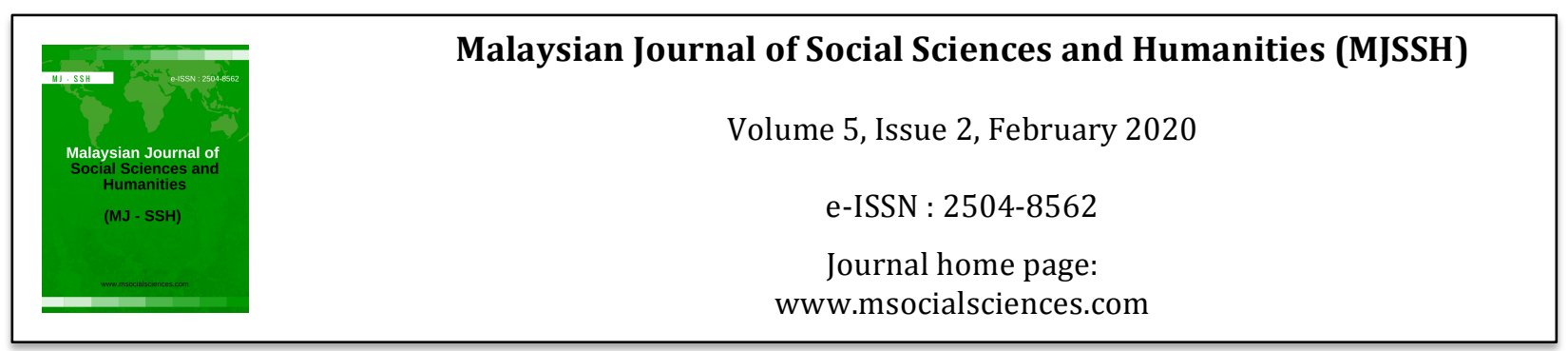

\title{
Women Volunteerism for Protecting Watershed Ecosystem in Langat Basin
}

\author{
Devika Krishnan ${ }^{1}$, Shaharuddin Mohamad Ismail ${ }^{2}$, Chamhur Siwari ${ }^{2}$, Sara Kaffashi ${ }^{3}$, Shaharuddin \\ Pushpawani Ramaloo² \\ ${ }^{1}$ Faculty of Administrative Science and Policy Studies, Universiti Teknologi Mara (UiTM) \\ 2Institute for Environment and Development (LESTARI), Universiti Kebangsaan Malaysia (UKM) \\ 3School of Management, Cranfield University
}

Correspondence: Devika Krishnan (devika@uitm.edu.my)

\begin{abstract}
Forested watershed provides abundant ecosystem services for water users including catchment area protection, flood regulation, provisioning of clean drinking water and climate regulation. However, the value of ecosystem services only partially takes into account by policy makers and indirectly cause overexploitation of natural resources. This study observes the economic role of women in protecting watershed ecosystem by calculating willingness to pay (WTP). Langat Basin is an imperative watershed that supplying fresh water source and other necessities to approximately 1.2 million people within the catchment area. Langat Basin has getting the effect of hasty growth through industrialization and land development actions. Women within Langat Basin has been selected through face to face interview for measure willingness to pay (WTP) towards ecosystem protection. Single Bounded Dichotomous Choice technique in Contingent Valuation Method (CVM) is engaged to calculate WTP of women. Willingness to pay of women in upstream is RM184.28, followed by women in middle stream is RM168.60 and lastly WTP of women in downstream is RM190.16. The willingness to pay women shows that women has potential to be part of ecosystem protection and signal to policy makers to include women in decision making process especially for environmental perspective.
\end{abstract}

Keywords: women, environment, volunteerism, willingness to pay

\section{Introduction}

Environment is vital aspect of whole ecosystem on the earth. Forested watershed provides abundant ecosystem services to water users including catchment area protection, biodiversity management, scenery beauty, carbon sequestration, nutrient cycling, soil formation and flood regulation, provisioning of clean drinking water and climate regulation. The emergence of a market for watershed services has not been associated with noteworthy impact to ecosystem services. UN Agenda 21 in 1992 has indicated that women as significant component in promoting sustainable development. In this plan, involvement, fairness, and acceptance of female were highlighted as key factors for sustainable development ( $\mathrm{Lv} \&$ Deng, 2019). Usefulness of female's involvement in conserving environment remonstrated in 6th meeting of UN as well as in $5^{\text {th }}$ goal of Sustainable Development Goals (SDG). Globally the participation and volunteerism of women community toward environmental protection increase abruptly. Rising number of recognition for women's effort to conserving environment is clearly visible when Kenyan environmentalist Prof. Dr. Wangari Maathai has been awarded noble peace prize in 2004. Noble prize symbolizes protecting and restoring the environment contributes to 
peace (Maathai, 2013). Therefore, women known as role players in natural capital administration and also major contributors to environment reclamation and protection (Wuyep et al., 2014). Women play vital role in addressing environmental issues due to their connection with environment. The revolution of women from a house maker to a political leader, policy maker, researcher, and environmentalist are fundamental changes toward sustainable development. Women being predominantly accountable for internal and domiciliary administration that connect natural and human made environment more than men. This study focusing on women role in watershed protection services in Langat basin.

\section{Material and Methods}

This section explains about physical characteristic of Langat Basin and methods that has been applied to measure women's willingness to pay towards watershed protection in this study.

\section{Site Description}

This research paper is partial result of doctorate research which only consist 277 respondents in Langat basin. According to Population and Housing Census of Malaysia in 2010, Selangor is serving approximately 5.4 million populations (Population Distribution and Basic Demographic Characteristic Report, 2010). Langat River is recognized as an imperative water source that supplying water to the consumer. Apart from water supply, Langat River also playing prominent role such as for an enjoyment, fishing, sewerage waste, irrigation, and sand quarrying (Juahir, 2009). Lately, Langat river was visible to various contamination complications from factories, household waste, farming and sand quarrying. Furthermore, Langat Basin is one of the areas under development pressure. This also negatively affects the supply of water resources to consumers (Devika, 2017). Langat water catchment area is continuously exploited through land development activities. The quality of the Langat Basin is categorized into moderate contaminated groups where it can potentially be polluted in the future (Compendium of Environment Statistics, 2014). The problem of pollution is due to the attitude of some irresponsible users in ensuring cleanliness (Devika, 2017). Even though, forested ecosystem benefits local and global societies, but not all forest based practices produce monetary revenues adequate with their "true" economic value. Numerous forest benefits, especially ecosystem services, are not traded in markets and have no recognizable value (Landell-Mills \& Porras, 2002). The sampling areas for this study consist of the woman households who live within Langat river basin areas. Langat Basin area has been divided into three stages: upstream, middle stream and downstream.

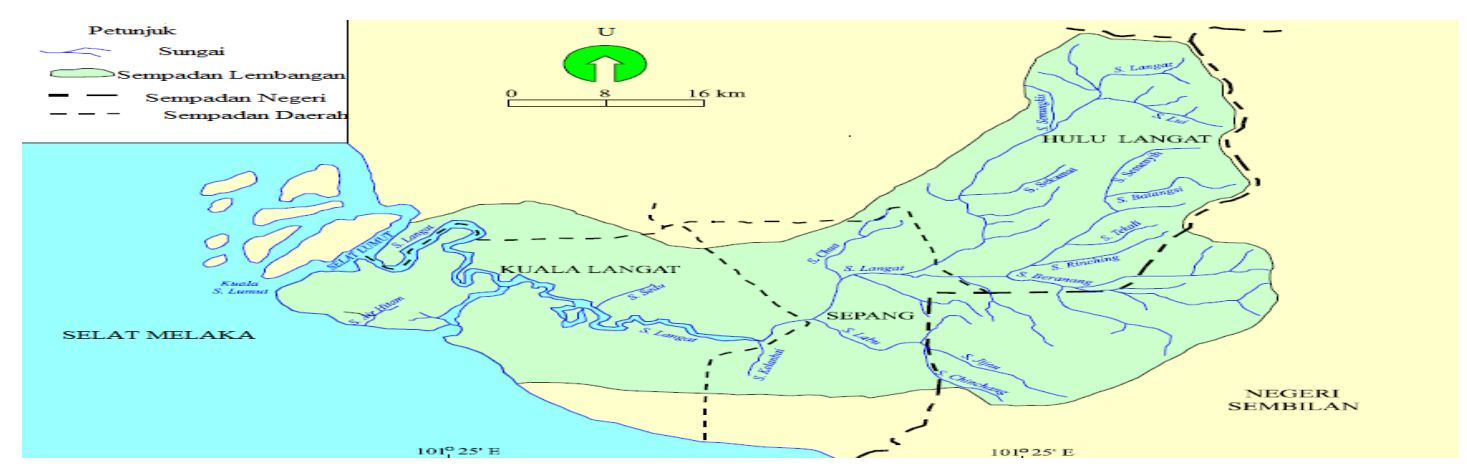

(Source: Juahir, 2009)

Figure 1: Location of Langat Basin

\section{Method of Study}

The Contingent Valuation Method (CVM) has been the preferred approach and is most extensively used to measure ecosystem services. This CV method has been widely employed in various research 
DOI: https://doi.org/10.47405/mjssh.v5i2.356

field such as studies on renewable energy (Lee \& Heo, 2016), air pollution and smog mitigation (Sun et al., 2016), wetland conservation efforts (Schuhmann et al., 2019) and watershed protection (Devika, 2017). There are three types of technique in CV method such as single bounded modelling, double bounded modelling and multiple bounded modelling. Researcher has employed Single bounded modelling because it's easy to deal with the respondents (Haneman et al., 1991). The CVM survey was prepared with 277 forms distributed and structured interviews were conducted physically using a random sampling procedure which involved residents aged 18 and above in the state of Selangor. Face to face approach applied due to the firm benefits primarily to calculate intricate range of ecosystem services (Verbič \& Slabe-Erker, 2008). This process of conducting a CVM study and face-to-face interviews was followed by an NOAA panel data (Arrow et al., 1993). The questionnaire was pretested among 50 households to scrutinise understanding of questions and design of bid amount before proceed to real survey. The bids that used in survey are 5MYR, 10MYR, 15MYR, 20MYR, 25MYR and 30MYR.

\section{Findings}

This section describes socio-economic analysis of respondents and willingness to pay of women in Langat Basin.

\section{Socio-economic Analysis}

This part determines the outcome of single bounded CVM using descriptive and econometric analysis. Table 1 presented the socioeconomic characteristics of 277 respondents in upstream, middle stream and downstream in the survey. From total number of respondents 94 respondents from upstream area, 86 respondents from middle stream area and remaining 97 respondents from downstream area. Mean age of respondents in upstream is 37 years where slightly high compare to mean age of respondents in middle stream is 35 years and mean age of respondents in downstream is 36 years. In upstream area out of 94 respondents $28.7 \%$ respondents were single, $66 \%$ respondents were married and $5.3 \%$ respondents were divorced. In middle stream area from total number of respondents, $26.7 \%$ respondents were single, $72 \%$ respondents were married and $2.3 \%$ respondents were divorced. In downstream, $17.5 \%$ respondents were single, $76.3 \%$ respondents were married and $6.2 \%$ respondents were divorcee. Majority respondents from all three areas were married women. In the aspect of education level of respondents, majority women were from secondary education in upstream (38\%), middle stream (11\%) and downstream (22\%). Furthermore, the greater number of respondents from all these area were formal schooling. Women respondents in upstream and middle stream area were mainly were unemployed compare to downstream respondents were majority were management staff in government sector. Unemployed women are house makers who well verse on ecosystem and household waste management. It's believed that top management staff are educated and keen to do sustainable decision making toward ecosystem management. Mean monthly income of upstream women respondents posted the highest RM5306.34 followed by middle stream mean monthly income RM 4593.02 and finally mean monthly income in downstream RM 4113.40. Mean willingness to pay (WTP) of women in upstream is RM 184.28, WTP of women in middle stream is RM 168.60 and mean WTP of women in downstream is RM190.16.

Table 1: Socio-economic analysis of respondents $(\mathrm{n}=277)$

\begin{tabular}{lcccccc}
\hline Demographic & \multicolumn{2}{c}{ Upstream } & \multicolumn{2}{c}{ Middle stream } & \multicolumn{2}{c}{ Downstream } \\
\cline { 2 - 7 } Characteristic & Frequency & $\%$ & Frequency & $\%$ & Frequency & $\%$ \\
\hline No. of respondents & 94 & \multicolumn{7}{c}{86} & & 97 & \\
\hline Age (Mean) & 37 & & 35 & & 36 & \\
\hline Civil Status & 27 & 28.7 & 23 & 26.7 & 17 & 17.5 \\
Single & 62 & 66 & 62 & 72 & 74 & 76.3 \\
Married & 5 & 5.3 & 2 & 2.3 & 6 & 6.2 \\
Divorced & & & & & & \\
\hline Education Level & & & & & & \\
\hline
\end{tabular}


DOI: https://doi.org/10.47405/mjssh.v5i2.356

\begin{tabular}{lcccccc}
\hline No formal schooling & 3 & 3.2 & 9 & 10.5 & 9 & 9.3 \\
Primary school & 11 & 11.7 & 6 & 7 & 4 & 4.1 \\
Secondary school & 36 & 38.3 & 25 & 29 & 22 & 22.7 \\
Polytechnic & 7 & 7.4 & 18 & 20.9 & 12 & 13.4 \\
College & 13 & 13.8 & 13 & 15.1 & 28 & 28.8 \\
University & 24 & 25.5 & 15 & 17.4 & 22 & 22.7 \\
\hline Occupation & & & & & & \\
Unemployed & 24 & 25.5 & 20 & 23.3 & 16 & 16.5 \\
Labor & - & - & 10 & 11.6 & 7 & 7.2 \\
Government & & & & & & \\
Management & 18 & 19.1 & 10 & 11.6 & 26 & 26.8 \\
Supporting & 6 & 6.2 & 19 & 22.1 & 8 & 8.2 \\
Private & & & & & & \\
Management & 20 & 21.3 & 12 & 13.9 & 8 & 8.2 \\
Supporting & 14 & 14.9 & 1 & 1.2 & 17 & 17.5 \\
Self-employed & 12 & 12.8 & 14 & 16.3 & 15 & 15.5 \\
\hline Mean Monthly & 5306.34 & & 4593.02 & & 4113.40 & \\
Income (RM) & & & & & & \\
\hline Mean WTP (RM) & 184.28 & & 168.60 & & 190.16 & \\
\hline
\end{tabular}

\section{Willingness to Pay of Women}

Table 3 shows single bounded method results in Contingent Valuation Methods (CVM). Before begin the real survey, respondents were questioned about addition in current water tariff. About $100 \%$ respondent in upstream, $96.5 \%$ in middle stream and $98.9 \%$ in downstream have mentioned that they willing to pay for any additional charges for water in future. The reason of paying of respondents were to protect the ecosystem services in Langat Basin.

Table 2: Respondent's WTP for additional water charges

\begin{tabular}{lcc}
\hline WTP & Frequency & Percentage (\%) \\
\hline Upstream & Yes: 94 & 100 \\
& No : 0 & 0 \\
Middle stream & Yes: 83 & 96.5 \\
& No: 3 & 3.5 \\
Downstream & Yes: 96 & 98.9 \\
& No: 1 & 1 \\
\hline
\end{tabular}

Based on table 3, lower bid amount is significant at $95 \%$ confidence interval in upstream area, in middle stream area lower bid amount and monthly income is significant and in downstream area age, education level, monthly income and lower bid amount have weak relationship with WTP. $1 \%$ increase in lower bid amount will reduce willingness to pay about $9.61 \%$. In middle stream area, monthly income and lower bid amount are significant variable where $1 \%$ increase in monthly income and lower bid amount will increase willingness to pay $112 \%$ and $84.5 \%$ respectively. Furthermore, in downstream area, variables are negatively related to WTP. Table 3 showed WTP of women in Langat Basin toward environmental protection. The WTP results indicated women in upstream area have higher WTP compare to women in middle stream and downstream. WTP of women in middle stream is RM168.60 lower than WTP of women in downstream. WTP of women in Langat basin showed an overwhelming awareness on watershed ecosystems which partially contaminated and potentially be polluted in the future. Dupont (2004) recommended that women are willing to pay more to avoid environmental health threats for their kids. However, according to Carlsson et al., (2010) female respondents present lower amount of money for ecological and fair-trade coffee. Economic rate for conservation of urban trees and environmental services in Benin City, Nigeria is US\$1.20/month (Arabomena et al,. 2019). The annual willingness to pay of forested watershed in Langat Basin stated low compare to Opequon 
DOI: https://doi.org/10.47405/mjssh.v5i2.356

Watershed $\$ 48$ (Benson 2006). This situation may portray the difference in socioeconomic aspect of respondents in study area.

Table 3: Single bounded method in Contingent Valuation Methods (CVM)

\begin{tabular}{|c|c|c|c|c|c|c|}
\hline \multirow{6}{*}{ 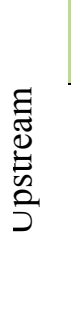 } & Variable & Coefficient & $\begin{array}{l}\text { Standard } \\
\text { Error }\end{array}$ & b/St.Er & $\mathrm{P}[|\mathrm{Z}|>\mathrm{Z}]$ & Mean of X \\
\hline & Constant & 4.13637248 & 4.55657868 & 0.908 & 0.3640 & \\
\hline & Age & -0.02005822 & 0.02002454 & -1.002 & $0.3165^{* * *}$ & 37.8085106 \\
\hline & Edu & 0.16816389 & 0.15642747 & 1.075 & $0.2824 * * *$ & 3.93617021 \\
\hline & Linc & -0.15766097 & 0.49902372 & -0.316 & $0.7520 * * *$ & 8.48174108 \\
\hline & LBD & -0.96128043 & 0.39326433 & -2.444 & $0.0145^{*}$ & 2.70287528 \\
\hline \multirow{10}{*}{ 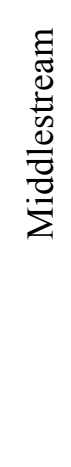 } & Constant & -4.37107972 & 3.55451659 & -1.230 & $0.2188 * * *$ & \\
\hline & Age & -0.01918438 & 0.02828816 & -0.678 & $0.4977 * * *$ & 35.3023256 \\
\hline & Edu & -0.23952803 & 0.19443204 & -1.232 & $0.2180 * * *$ & 3.75581395 \\
\hline & Linc & 1.12249004 & 0.45785036 & 2.452 & $0.0142 *$ & 8.24623847 \\
\hline & Lbd & -0.84531797 & 0.44115661 & -1.916 & $0.0553^{* *}$ & 2.63555484 \\
\hline & Constant & 11.0625239 & 5.44684675 & 2.031 & 0.0423 & \\
\hline & Age & -0.00832681 & 0.03124067 & -0.267 & $0.7898 * * *$ & 36.9793814 \\
\hline & Edu & -0.29316566 & 0.19485457 & -1.505 & $0.1324 * * *$ & 4.15463918 \\
\hline & Linc & -0.94770736 & 0.67491913 & -1.404 & $0.1603 * * *$ & 8.23528356 \\
\hline & Lbd & -0.12109128 & 0.44452385 & -0.272 & $0.7853 * * *$ & 2.65028147 \\
\hline
\end{tabular}

\section{Conclusion}

In this study we present an analysis of willingness to pay (WTP) of women in Langat Basin using Contingent Valuation Methods (CVM), Single Bounded Dichotomous Choice. Langat Basin has been divided into three areas: upstream, middle stream and downstream. Willingness to pay of women in Langat Basin presents valuation of watershed ecosystem services is essential in order to manage water services sustainably. This suggests many reported willingness to pay toward environmental conservation by consumers are practical as well as from women perspective. In addition, our findings demonstrate that women volunteerism toward water conservation is highly fortified. These results highlight the Contingent Valuation Methods analysis toward value of ecosystem services for current and future generations. This will ultimately contribute to more realistic estimates of willingness to pay in order to conserve watershed ecosystem protection.

\section{Acknowledgement}

Authors greatly acknowledge the Ministry of higher education for MyBrain scholarship in order to complete the Ph.D research. Authors also would like to acknowledge government agencies of Malaysia for their guidance and respondents of this research for their information.

\section{References}

Ali, M. F., Rahman, N. F. A., Khalid, K., \& Liem, N. D. 2014. Langat river basin hydrologic model using integrated GIS and ArcSWAT interface. In Applied Mechanics and Materials, 567, 86-91.

Arabomena, O. J., Chirwaa, P. W., \& Babalolaa, F. D. 2019. Willingness-to-pay for Environmental Services Provided By Trees in Core and Fringe Areas of Benin City, Nigeria 1. International Forestry Review, 21(1), 23-36.

Arrow, K., R. Solow, P.R. Portney, E.E. Leamer, R. Radner, and H. Schuman. 1993. Report of the NOAA panel on contingent valuation. Federal Register 58(10):4601-4614. 
DOI: https://doi.org/10.47405/mjssh.v5i2.356

Benson, M. C. 2006. An economic valuation of improved water quality in Opequon watershed(Doctoraldissertation, WestVirginiaUniversity).

Carlsson, F.; Garcia, J.H.; Lofgren, A. Conformity and the Demand for Environmental Goods. Environ. Resour. Econ. 2010, 47, 407-421.

Devika Krishnan. 2017. Kesanggupan membayar isirumah bagi fungsi perlindungan Kawasan hutan tadahan air dengan menggunakan instrumen Bayaran perkhidmatan ekosistem (PES): Kajian kes di Lembangan Langat, Selangor dan pengalaman Perbadanan Tenaga Hidro Boleh Diperbaharui Perak (PHREC). Universiti Kebangsaan Malaysia.

Dietz, T.; Stern, P.; Guagnano, G. Social Structural and Social Psychological Bases of Environmental Concern. Environ. Behav. 1998, 30, 450-471.

Dupont, D.P. Do Children Matter? An Examination of Gender Differences in Environmental Valuation. Ecol. Econ. 2004, 49, 273-286.

Green Belt Movement. 2019. Wangari Maathai. Available at : https://www.greenbeltmovement.org/wangari-maathai [Accessed on 15 May 2019]

Goel, P. K. (2006). Water pollution: causes, effects and control. New Age International.

Hanemann M, Loomis J and Kanninen B. 1991. Statistical Efficiency of Double-bounded Dichotomous Choice Contingent Valuation. Am. J. Agric. Econ. 73: 12551263.

Juahir, H. 2008. Water Quality Data Analysis and Modeling at Langat River Basin. PhD dissertation, Universiti Putra Malaysia.

Kadhum, S. A., Ishak, M. Y., Zulkifli, S. Z., \& binti Hashim, R. 2015. Evaluation of the status and distributions of heavy metal pollution in surface sediments of the Langat River Basin in Selangor Malaysia. Marine pollution bulletin, 101(1), 391-396.

Landell-Mills, N., \& Porras, I. T. 2002. Silver bullet or fools' gold?: a global review of markets for forest environmental services and their impact on the poor. London: International Institute for Environment and Development.

Lee, C. Y., \& Heo, H. 2016. Estimating willingness to pay for renewable energy in South Korea using the contingent valuation method. Energy Policy, 94, 150-156.

Lv, Z., \& Deng, C. 2019. Does women's political empowerment matter for improving the environment? A heterogeneous dynamic panel analysis. Sustainable Development.

Schuhmann, P. W., Skeete, R., Waite, R., Lorde, T., Bangwayo-Skeete, P., Oxenford, H. A., ... \& Spencer, F. 2019. Visitors' willingness to pay marine conservation fees in Barbados. Tourism Management, 71, 315-326.

Sun, C., Yuan, X., \& Yao, X. 2016. Social acceptance towards the air pollution in China: evidence from public's willingness to pay for smog mitigation. Energy Policy, 92, 313-324.

Maathai, W. (2013). Unbowed. Field Actions Science Reports. The journal of field actions, (Special Issue 7).

Wuyep, S. Z., Dung, V. C., Buhari, A. H., Madaki, D. H., \& Bitrus, B. A. 2014. Women participation in environmental protection and management: Lessons from plateau state, Nigeria. American Journal of Environmental Protection, 2(2), 32-36. 